\title{
Building the Bridge between Higher Learning Institution and Social Media Technologies through Mobile Learning in Malaysia
}

\author{
Kalaimagal Ramakrishnan, Norian Mohd Yasin, KR Selvaraj, .Jeyarani Periyasamy
}

\begin{abstract}
The Malaysian government sees education as one of the important factors in the country's advancement. In order to achieve this, Malaysia needs to have an up-to-date technology such as Social Media Technologies (SMTs) to support the learning system in Higher learning institutions (HLIs). There is a great argument that 21st Century students learn differently. SMTs help to form a student-centered environments among the digital generation. It bridges a gap in knowledge in relation between SMTs and its impact in HLIs. Mobile learning and SMTs deliver the ability to communicate with academicians and students. HLIs should take this opportunity to connect SMTs to design a modern educational setting that will advance their learning experiences. It shows that SMTs have a great value for academic associated, particularly as a teaching and learning tool. HLIs and students have identified numerous challenges related to the adoption process. This study reviews and evaluates the SMTs related research articles published in academic journals between the year 2010 to 2018, mainly in HLIs fields. It identifies the impacts of SMTs on both students and academicianss in HLIs and associate how SMTs can be effectively connected to Mobile learning to support and enhance the students' learning in Malaysia.
\end{abstract}

Keywords: Learning Institution; Social Media Technologies; Mobile learning.

\section{INTRODUCTION}

Education is the most powerful and valuable instrument of social advancement and development in this $21^{\text {st }}$ century. As we are aware, Higher learning institutions (HLIs) are facing new challenges and issues from the public. Today's Technology in communication has directed the world into a Global village as long as they have adigital device connected to Internet. Innovative teaching practice in HLIs is one of the important approaches to enhance the educational quality for the students. One of the effective ways is to is to use technology such as Social Media Technologies (SMTs) to support the learning system. Academicians play a very important role for the success of implementation SMTs in HLIs (Minocha, Schroeder, \& Schneider, 2011). In many HLIs, learning are conducted in

Revised Manuscript Received on April 19, 2019.

Kalaimagal Ramakrishnan, University of Nottingham Malaysia Campus Jalan Broga, Semenyih, 43500 Selangor, Malaysia. (Email: Kalaimagal.ramakrishnan@nottingham.edu.my)

Norian Mohd Yasin, University of Malaya Jalan Universiti, 50603 Kuala Lumpur, Malaysia. (Email: Norizan@um.edu.my)

KR Selvaraj, University of Nottingham Malaysia Campus Jalan Broga, Semenyih, 43500 Selangor, Malaysia. (Email: KRSelvaraj@ nottingham.edu.my)

Jeyarani Periyasamy, INTI International University Persiaran Perdana BBN, Putra Nilai, 71800 Nilai, Negeri Sembilan, Malaysia. (Email:Jeyarai@newinti.edu.my) classroom by providing instruction to the students (White, Bloomfield, \& Le Cornu, 2010). Majority of the formal teaching methods adopted at HLIs have been based on formal lectures, individual learning and followed the structured teaching approaches (Al-Sabaawi \& Dahlan, 2018). Students from Generation $Y$ are called digital natives because they are use with digital surroundings. Besides that, Information Technology affects how they live (Bennett, Bishop, Dalgarno, Waycott, \& Kennedy, 2012) (Werner, Lehl, \& Walton, 2017). Generation Y prefer to involve, shares, find and use the content on SMTs. Anyone born after 2002 referred as Generation Z. This population will be growing up with SMTs, smart phones and applications (Benckendorff \& Moscardo, 2015). This will force the society to become more dependent on technology. So, in order to manage the students from Generation Z, HLIs need to master the tools of SMTs for a successful teaching and learning environment.

By conducting innovative teaching among the students, it will help them to meet the goals of transformation and challenges in the 21st century (Khadimally, 2017). SMTs play important role to create the student-centered setting that supplies the need of the digital natives. In this digital era, the students are very benefited by having access to mobile devices and digital content without much boundary (Ting, Ng, Ooi, \& Yap, 2018). The biggest challenge the academicians in HLIs is to motivate their students to gain the knowledge and play an active role in their learning (Felder \& Brent, 2010). Today, when we walk into a class, we could see almost all the students are using their mobiles or other digital devices than talking to their friends. Nowadays, asking the students to keep their mobiles and concentrate the lesson in class is a real challenge to most academicians. With this environment, another concern of HLIs is how SMTs could be used efficiently, which could contribute to an effective learning experience for the digital students. This study identifies the impacts of SMTs on both students and academicians in HLIs and associate how SMTs can be effectively connected to Mobile learning to support and enhance the students' learning in Malaysia.

\section{METHODOLOGY}

Firstly, the study went through a concrete review of the literature. The study methodically searched the following

Published By: 
focused database sources from Web of Science. In addition to that, Google Scholar was used to find more information on the discussed topic. The literature reviews were also extracted from the academic databases. Some of the search words and phrases are Social media, Social Media Technologies, Higher Learning Institution, Social Media Technologies in Higher Learning Institution, Social Media Technologies in University, Social Networking and Web 2.0. The study focused on papers published since year 2010 until 2018. The Exponential non-discriminative snowball sampling method was used to accumulate the knowledge on the topic. The research findings systematically establish the tactical importance of SMTs in HLIs. This study also contributes to the academia the importance of SMTs in HLIs and provide an agenda for future research. Many researchers debate for the integration of SMTs in HLIs as an educational apparatus. Empirical evidence, however, has lagged in supporting the claim. Most of the present research on bridging between Higher Learning Institution and Social Media Technologies are limited to self-reported data and content analyses. This paper summarizes the scholarly writings as well as reviews the findings of empirical investigations. Some limitations are discussed, and future areas of research are proposed.

\section{LITERATURE ON SMTS \& MOBILE LEARNING}

Social media utilize mobile device and web based technology to create high interactive stand which allow the individuals and community share, discuss the content (Desmal, 2017). Social media technologies (SMTs) refers to a group of Internet based application where content are created and exchanged (Tang \& Patrick, 2018). SMTs generally distinguished by digital platforms where the users can create, share, and interact with content and each other in online collaborative spaces. This could be carried out with the assistance of SMTs, such as Facebook, Twitter, Yahoo Messenger, Whats app messenger and Skype. (Kaplan \& Haenlein, 2010) classified SMTs into six different classes viz "Collaborative Project (Wikipedia), Blogs and Micro blogs (Twitter), Content Communities (Youtube), Social Networking Site (Facebook; 2go; BB chat), Virtual Game World (World of war craft) and Virtual Second World (Second life)". According to (Al Musawi, 2017), SMTs have been defined more by the platform then by the use, ranging from generic SMTs (Twitter, Facebook), professional and academic networking services (LinkedIn, ResearchGate), tools to write and comment (Blog, Wiki) and to archive and retrieve content material for lectures and groupwork (Podcast, YouTube and Vimeo, SlideShare). The rise of the SMTs has changed the way people work, communicate, socialize and learn as a 'network society'. Academicians in HLIs need to care not only about what they are teaching but also about how they are mediating the topics to their students. Althoguh SMTs offer important resource in HLIs, studies however shows that students does not use them for their educational use but to waste their time (Cummings \& Mather, 2017).

In mobile social media, mobile devices will work together SMTs which differs from the traditional social media. The use of mobile devices offers a wide variety of possibilities to distribute content of all kind. In HLIs, the role of technology has developed from a computer assisted learning model in the 1970s, based on mainframe technologies to today's Internet era where mobile technologies are the norm (Tsai, Tsai, \& Hwang, 2012). In $21^{\text {st }}$ centuary, the mobile technologies use in the educational sectors has glowed. Mobile learning uses mobile technologies such as smartphones, laptops, iPads, tablets or any wearable technologies for learning (Traxler, 2017). Mobile devices help to consider and recognize the preferences that students have when they are processing, analyzing and transmitting knowledge. Many academicians and students in HLIs started using mobile technologies in classrooms. Many publications have explored the possible and limitations of these technologies in HLIs (Crompton \& Traxler, 2018); (Traxler, 2013). The integration of mobile devices in the educational field enhances the construction of more creative and significant environments for the learning achievement (Feng \& Zhao, 2016). Mobile devices give academicians the flexible tools for complementing existing technologies and extend the learning beyond the classroom because they are highly individualised and collaborative tools (Hamidi \& Chavoshi, 2018) . According to (Al Musawi, 2017) \& (Al Hamdani, 2013), the academicians recognize a potential in mobile applications to distribute content, support teaching activities and facilitate the transfer and retention of knowledge.

Mobile learning (M-learning) provides the flexibility to communicate with academicians and peers, as well as their access learning resources. M-learning) offers a more flexible education environment for the students. Besides that, it also introduce more attractive, motivating and technologically enhanced learning materials. Students are allowed to take charge of their learning process within and outside their classroom with the support of M-learning technologies. Besides that, M-learning offer the students to organize their learning in a different way (Woodill, 2015). The low cost, accessibility and user friendly mobile devices have increased their popularity among students and academicians in HLIs. According to (Kaur \& Bhullar, 2013), some of the unique features of mobile devices are it's small size and insightful. It will increase the task completion rates. which will help to minimize students' anxiety and increase their levels of confident in their studies and promote motivation in their HLIs environment. In addition,mobile deceives allow more freedom in movement and interaction (AlEmran, Elsherif, \& Shaalan, 2016) \& (Al-Adwan, AlAdwan, \& Berger, 2018).

\section{ADVANTAGES OF SMTS IN HLIS}

There are many advantages of SMTs in HLIs. Information sharing with SMTs using mobile device in HLIs provide positive effect to HLIs students (Tang \& Patrick, 2018).

SMTs in HLIs serves as an online platform between the students and the academicians to extend the classroom beyond the classroom walls. Besides that, it provide flexible timings for students to interact with the academicians to

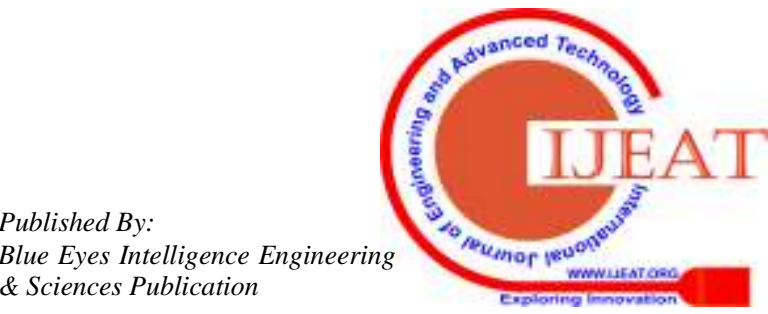


clear their doubts. So, the students will be able to get immediate feedback than waiting for the following classes to clear their doubts. According to(Acarli \& Saglam, 2015), student's ability to work on the assigned task at their own pace and in flexible timings made SMTs established among students.

SMTs also give the flexibility for the academicians to reach their students with no trouble, even when they are outside of HLIs (Bessette \& Burton, 2014). Besides that, the academicians may provide instant suggestion on posts and able to offer additional help and guide their students who need their help. It enables the academicians to keep track of their students' performance to enrich their learning experience. So, academicians may use SMTs as a forum or a blog for communiation process (Barbosa, Bassani, Martins, Mossmann, \& Barbosa, 2016).

SMTs also engage students in discussion and monitor their performance. With the existence of SMTs, it also allow them to differentiate the content based on the students reception. According to (Akeriwa, Penzhorn, \& Holmner, 2015), SMTs will draw the students' attention and motivate their participation. It also icreases the quality of interaction among the students and their academicians (Cummings \& Mather, 2017). SMTs among academicians and students will also be more active as we could send notifications on updated activities which encourages collaborative learning. It also could encourage online discussion among students outside their classrooms. (Zgoda \& Shane, 2018) added that, SMTs also improve students' construction of understanding and promote student interaction. By having cooperative learning, they will be able to advance their peer connection, which ultimately produce new ideas (Crompton \& Traxler, 2018). SMTs also could enhance students' creativity. Since collaborative discussion taken place, it would encourage critical thinking (Heavin \& Neville, 2012).

According to (Ahmadi, Noroozi, \& Mohamadi, 2013), the students have different expectations and learning styles. It was found that SMTs are mainly exploited to visualize the available resources (Al Hamdani, 2013). They added that, SMTs in HLIs are mainly to share contents rather than to produce content.This is added by (Arshad, Ahmad, \& Siddiqui, 2018) that, SMTs increases popularity among students and the potential effect on academic performance. It was also described that SMTs have a meaningful effect on the students' academic performances in terms of the students' understanding. The SMTs tool such as the blog, chat and forum tool could encourage and motivate the students to reflect and also to experience the inner mechanics of a subject and to make the relevant connections to further their understanding.

Education is a complex process. The effectiveness in an education is influenced by many surrounding factors. SMTs also can be used as a collaborative learning. This could create effective learning among the students. With the active interaction with peer studens and academicians, it could promote active collaborative learning, which ultimately enhance the students' academic performance. SMTs have significant positive effect on collaborative learning (AlEmran et al., 2016). (Alwi, Mahir, \& Ismail, 2014) stressed that SMTs encourage the development of "collective intelligence". So, SMTs are mainly designed to encourage students to interact together in knowledge building. Besides collaborating with their academicians through SMTs, students can also obtain useful information through collaboration (Ford \& Leinonen, 2009). Besides that, SMTs also could highlight the deficiencies of the members' knowledge in the group, or encourage the whole group on the topic discussed. This will help the students to achieve better academic results. (Gasmi, 2014) added that, students' involvement in learning with SMTs have improved with a keen interest shown in posting doubts and sharing materials withclassmates. The interaction between teacher - student and student - student has created the culture of collaborative learning amongst them. Besides that, the students' contribution towards learning, increased due to easy access on mobile devices. This will enhance the classroom learning more interactive and collaborative while providing the necessary support as and when required. This environment will prove better learning environment for the students compared to the traditional HLIs assessment practices which are individualistic and competitive. So, SMTs are not only focusing on knowledge transfer among the students in the group but it also assist the students' promote collaborative learning (Redecker \& Punie, 2010). (Wankel, 2011) stressed that SMTs such as Facebook are the top SMT that students are comfortably using for collaboration purpose in their HLIs. By sharing the same LMS information on SMTs, the academicians are diverting their teaching from content-based learning to process-based learning. This will shift the passive learning to active learning (Akeriwa et al., 2015). However, video sharing services such as YouTube, and wikis such as Wikipedia are also a top choice for the students. SMTs also help the students to deepen their view, approach and perception of their content (Ting et al., 2018). Kahoot! is one of the tools that has been increasingly used in HLIs with good results (Arshad et al., 2018). So, by using SMTs in HLIs, it provides sufficient understanding transfer and contributes to student learning performance improvement.

By collaborating SMTs in HLIs, mobile learning embraces the potential to engage students and encourage learning anywhere at any time. SMTs that are provided on the Internet are mostly free or require marginal investment, eliminating a potential barrier to adoption. One of the major factors that encourage the adoption of SMTs is the flexibility the technologies offer to the users (Schroeder, Minocha, \& Schneider, 2010). The rise of the SMTs have changed the way people work and communicate. We could extend the classroom on SMTs platform known as Edmodo (online classroom). It provides opportunity for both students and academicians to connect in learning and sharing information on a virtual space $24 / 7$ and anywhere. This is similar to Facebook but is more secured. Only the user who receive the code is entitled to register in the group. After registration, they are allowed to access and join the group (Barbosa et al., 2016).

Students leveraging SMTs feel they are emotionaly connected with their peers in the group. This envolironment 
is very helpful for those individuals who have problems with face-to-face discussion (Junco, 2010). SMTs also enable better HLIs interaction with their students as it offers much informal way of communication (Mazer et al., 2007). Besides that, it also helps to strength the relationships between students, and will lead to a stronger classroom community virtually. With the flexibility that SMTs offer, academicians could improve their student satisfaction by offering a better student-teacher relationship outside their classroom.

\section{CHALLENGES OF SMTS IN HLI}

In $21^{\text {st }}$ Century educational environment, educational social technologies such as SMTs and the development of information society and in the "native digital", the academicians need to equally update them to the trend and make effective use of all the available educational technologies for their students' benefits. Although there are strong evidence of SMTs are increasingly in use within teaching and learning in HLIs, academicians and students have identified numerous challenges related to the SMTs adoption process.

According to (Tess, 2013), academicians are slow in adopting SMTs as an educational tool in HLI. Even those academicians who are practicing SMTs in the teaching and learning are in an experimental stage of implementation. The main reason for this to happen is because in most HLIs, the SMTs adoption is a choice made by the academicians and not the HLIs. SMTs adoption as an educational tool also presents many challenges, such as cultural conflict, pedagogical issues and lack of HLIs support. The results also indicated that teaching styles, demographic factors, previous experience and privacy issues could influence the decision to adopt SMTs for teaching purposes in HLIs.

(Jaafar, Darmawan, \& Ariffin, 2018) added that, academicians are not up-to-date and are not ready to take advantage of SMTs into their classes in HLIs. (Saeed, Yang, \& Sinnappan, 2009) stressed that, although many individuals started to use SMTs due to its advantages, but a major barrier remains to be "the limited understanding of students' characteristics and perceptions about the technology use".

Demographic variables such as gender, age, and seniority also affect the academicians use of SMTs in HLIs (Wankel, 2011). According to (Zhang, Chong, Pezeshki, Moran, \& Howard, 2012), age, the seniority was found as one of the important challenges of using SMTs in HLIs. According to the survery conducted, the younger academicians (below 35 years) from the faculty use SMTs at much higher rates in their teaching compared to the older academic generations. One of the main reason was because the senior academicians prefer to spend their time on their research than spending their time to discover new teaching practices. Besides that, they feel that they have greater self-confidence in teaching with the traditional teaching method and they face lesser career pressure. Gender also could be a challenge in SMTs use. According to (Broos, 2005) study, females have more negative attitude toward computers and the Internet than male users, and male users have lesser computer anxiety than females

According to (Cuban, Kirkpatrick, \& Peck, 2001), most professors or top position academicians value their research more compared to their teaching. This discourage them from spending more time for teaching. This clearly shows that, academicians prefer to adopt SMTs for personal and professional uses rather than for teaching purposes. Rise in anxiety among the academicians is another main challenge of SMTs. When the academicians have lack of knowledge or experience with technology and web applications, they have the fear to move forward to change their teacing style. Besides that, they also are not able to visualize how technology can be used in an academic setting.

One of the most commonly cited factors that influence the adoption of SMTs for teaching in HLIs was privacy issues and loss of control (Hussain, Cakir, \& Candeger, 2018), (Zgoda \& Shane, 2018), (Doinea, Batagan, \& Lancu, 2017), (Bayoumi, 2007). Academics' are concerned about the lack of inquiry-based learning, perceived privacy violations, plagiarism and time investments needed to effectively design SMTs enhanced learning tasks (Rambe, 2015). Another major factor that causes challenges for academics to use SMTs in their teaching is the lack of institutional or HLIs support (Rambe, 2015), (Waycott et al., 2013). This is because, the academicians need to get the approval from the policy makers in HLIs. The technical difficulties faced by students mostly involved poor network connectivity, limited batterylife, and application crashes (Baran, 2014).. Those students with lesser familiarit on SMTs may still need supervision and guidance (Rambe, 2015).

Researchers have pointed out that limited network capacity can have a negative impact on students' attitudes towards mobile learning since it can lead to interruptions and frustration. Networks in most HLIs were not built originally to deal with large numbers of mobiledevices. As a consequence, when many students try to access at the same time, they encountered an extremely slow transfer of data. So, it is importance to have an adequate technical infrastructure for m-learning at HLIs.Distraction is a common challenge associated with M-learning. Some of the strategies to reduce distractions caused by mobile technology are by providing explicit, clear policy regarding mobile use, orienting students to mobile etiquette, rolemodeling such etiquette, andreinforcing it through the course syllabus. This is added by (Al-Rahmi, Alias, Othman, Alzahrani, et al., 2018) that, SMTs are distracting the students from studying and lead to academic challenges. Besides that, it also give negative impact on the students' study habits (Ahmad, 2018).

Although students spend lots of their time participating in SMTs' activities, many students are blaming SMTs for their overall decrease in grade point averages (Kimberly, Jeong and Lee, 2009). According to (Kubey, Lavin, \& Barrows, 2001), SMTs also give impairment in their educational performance. (Mulqueeny, Mingle, Kostyuk, Baker, \& Ocumpaugh, 2015), stressed in their study that, a huge group of students experienced less study time due to huge time spent on SMTs. (Junco, 2012) also added that, students who active in SMTs were less flourishing in their studies 
compared to the tradisional class. According to (Phielix et al., 2010), students' GPA decreased as much as they were engaged in SMTs. The study suggested the students should manage and monitor their time spent using SMTs.

\section{CONCLUSION}

SMTs in HLIs is a promising field of scholarship that virtues further investigation and detail study. Based on the literature study, many HLIs in Malaysia are not efficiently using SMTs for teaching and learning. Most of the academicians are using SMTs as an informal tool to communicate with their students. Studies also showed that, the senior academicians who do not update themselves with the technologies and unfamiliar with SMTs may have lack of confidence to integrate SMTs in their teaching and learning activities. As discussed earlier, there are many challenges the academicians are facing in implementing SMTs in their HLIs. Finally, HLIs plays an important role in the success of building the bridge between HLIs and SMTs through mobile learning in Malaysia. The outcomes of this component of the study will inform the next phase of the study by assessing the knowledge of existing university digital resources and SMTs facilities which contribute to knowledge sharing among HLIs' students, identify the impacts of SMTs on both students and academicians and finally study on how SMTs can be effectively connected to Mobile learning to support and enhance the HLIs' students' learning. Although HLIs are facing a lot of challenges in adapting new technologies such as SMTs in their educational field, but they also have opportunities for improvement and innovative teaching and learning environment in HLIs.

\section{ACKNOWLEDGEMENT}

This research work is supported financially by Faculty of Science, University of Nottingham Malaysia Campus.

\section{REFERENCES}

1. Acarli, D. S., \& Saglam, Y. (2015). Investigation of preservice teachers' intentions to use of social media in teaching activities within the framework of technology acceptance model. International Educational Technology Conference, Ietc 2014, 176, 709-713. doi:10.1016/j.sbspro.2015.01.530

2. Adi, A., \& Scotte, C. G. (2013). Barriers to Emerging Technology and Social Media Integration in Higher Education: Three Case Studies. Social Media in Higher Education: Teaching in Web 2.0, 334-354. doi:10.4018/978-1-4666-2970-7.ch017

3. Ahmad, T. (2018). Mobile phones as a learning tool: a lecturer's viewpoint. Society and Business Review, 13(2), 132-139. doi:10.1108/Sbr-03-2018-0021

4. Ahmadi, R., Noroozi, D., \& Mohamadi, B. (2013). Mobile learning: The introduction of online and offline mobile learning systems based on cellular phones. 2013 Fourth International Conference on E-Learning and ETeaching (Icelet), 36-39.

5. Ajjan, H., \& Hartshorne, R. (2008). Investigating faculty decisions to adopt Web 2.0 technologies: Theory and empirical tests. Internet and Higher Education, 11(2), 71-80. doi:10.1016/j.iheduc.2008.05.002
6. Akeriwa, M., Penzhorn, C., \& Holmner, M. (2015) Using mobile technologies for social media based library services at the University of Development Studies Library, Ghana. Information Development, 31(3), 284293. doi: $10.1177 / 0266666913515898$

7. Al-Adwan, A. S., Al-Adwan, A., \& Berger, H. (2018). Solving the mystery of mobile learning adoption in higher education. International Journal of Mobile Communications, 16(1), 24-49.

8. Al-Emran, M., Elsherif, H. M., \& Shaalan, K. (2016). Investigating attitudes towards the use of mobile learning in higher education. Computers in Human Behavior, 56, 93-102. doi:10.1016/j.chb.2015.11.033

9. Al-Rahmi, W. M., Alias, N., Othman, M. S., Alzahrani, A. I., Alfarraj, O., Saged, A. A., \& Rahman, N. S. A. (2018). Use of E-Learning by University Students in Malaysian Higher Educational Institutions: A Case in Universiti Teknologi Malaysia. Ieee Access, 6, 1426814276. doi:10.1109/Access.2018.2802325

10. Al-Rahmi, W. M., Alias, N., Othman, M. S., Marin, V. I., \& Tur, G. (2018). A model of factors affecting learning performance through the use of social media in Malaysian higher education. Computers \& Education, 121, 59-72. doi:10.1016/j.compedu.2018.02.010

11. Al-Sabaawi, M. Y. M., \& Dahlan, H. M. (2018). Acceptance Model of Social Media for Informal Learning. Recent Trends in Information and Communication Technology, 5, 679-687. doi:10.1007/978-3-319-59427-9_70

12. Al Hamdani, D. S. (2013). Mobile Learning: A Good Practice. 13th International Educational Technology Conference, $103, \quad 665-674$ doi:10.1016/j.sbspro.2013.10.386

13. Al Musawi, A. S. (2017). Use of social media in technology-enhanced learning. Transforming Education in the Gulf Region: Emerging Learning Technologies and Innovative Pedagogy for the 21st Century, 126-138.

14. Albadi, A. A. M. (2016). Twitter Mobile Application: A Source of Communicative and Authentic Learning. Journal of Teaching English for Specific and Academic Purposes, 4(1), 49-60.

15. Alwi, N. H. M., Mahir, N. A., \& Ismail, S. (2014). Infusing Social Media in Teaching and Learning (TnL) at Tertiary Institutions: A Case of Effective Communication in Universiti Sains Islam Malaysia (USIM). International Conference on Communication and Media 2014 (ICome'14) - Communication, Empowerment and Governance: The 21st Century Enigma, 155, 265-270. doi:10.1016/j.sbspro.2014.10.290

16. Arshad, M., Ahmad, S., \& Siddiqui, F. A. (2018). Social Media Technologies and Their Benefits in Higher Education Institutions: A Survey of Jazan University. Information Technologies and Learning Tools, 65(3), 91102.

17. Baran, E. (2014). A Review of Research on Mobile Learning in Teacher Education. Educational Technology \& Society, 17(4), 17-32.

18. Barbosa, D. N. F., Bassani, P. B. S., Martins, R. L., Mossmann, J. B., \& Barbosa, J. L. V. (2016). Using Mobile Learning in Formal and Non-formal Educational Settings. Learning and Collaboration Technologies, Lct 2016, 9753, 269-280. doi:10.1007/978-3-319-39483$1 \_25$ 
19. Bayoumi, F. (2007). Towards mobile learning. Proceedings of the Iasted European Conference on Internet and Multimedia Systems and Applications, 202207.

20. Benckendorff, P., \& Moscardo, G. (2015). Generation Y and the curriculum space. Routledge Handbook of Tourism and Hospitality Education, 422-439.

21. Bennett, S., Bishop, A., Dalgarno, B., Waycott, J., \& Kennedy, G. (2012). Implementing Web 2.0 technologies in higher education: A collective case study. Computers $\begin{array}{lll}\text { \& Education, } & 59(2), & 524-534\end{array}$ doi:10.1016/j.compedu.2011.12.022

22. Bessette, D., \& Burton, S. L. (2014). Methods in Digital Marketing through Social Media Technology to Advertise Higher Education Blended Learning Programs. Inted2014: 8th International Technology, Education and Development Conference, 4479-4486.

23. Broos, A. (2005). Gender and information and communication technologies (ICT) anxiety: Male selfassurance and female hesitation. Cyberpsychology \& Behavior, 8(1), 21-31. doi:DOI 10.1089/cpb.2005.8.21

24. Chen, B. Y., \& Bryer, T. (2012). Investigating Instructional Strategies for Using Social Media in Formal and Informal Learning. International Review of Research in Open and Distance Learning, 13(1), 87-104. doi:DOI 10.19173/irrodl.v13i1.1027

25. Crompton, H., \& Traxler, J. (2018). Learning With Mobile Devices. Encyclopedia of Information Science and Technology, 4th Edition, 6347-6360. doi:10.4018/978-1-5225-2255-3.ch552

26. Cuban, L., Kirkpatrick, H., \& Peck, C. (2001). High access and low use of technologies in high school classrooms: Explaining an apparent paradox. American Educational Research Journal, 38(4), 813-834. doi:Doi $10.3102 / 00028312038004813$

27. Cummings, E., \& Mather, C. (2017). Advancing Social Media and Mobile Technologies in Healthcare Education. Informatics-Basel, 4(4). doi:ARTN 3510.3390/informatics4040035

28. Desmal, A. J. M. (2017). The Impact of Using Social Media and Internet on Academic Performance: Case Study Bahrain Universities. Eai Endorsed Transactions on Scalable Information Systems, 4(13). doi:ARTN 210.4108/eai.28-6-2017.152748

29. Doinea, M., Batagan, L., \& Lancu, B. (2017). Active Learning - a New Paradigm in Mobile Education. Proceedings of the 16th International Conference on Informatics in Economy (Ie 2017): Education, Research \& Business Technologies, 134-139.

30. Ebner, M., Lienhardt, C., Rohs, M., \& Meyer, I. (2010). Microblogs in Higher Education - A chance to facilitate informal and process-oriented learning? Computers \& Education, $\quad 55(1), \quad 92-100$ doi:10.1016/j.compedu.2009.12.006

31. Englander, F., Terregrossa, R. A., \& Wang, Z. B. (2010). Internet use among college students: tool or toy? Educational Review, 62(1), 85-96. doi:Pii 92127285910.1080/00131910903519793

32. Felder, R. M., \& Brent, R. (2010). The National Effective Teaching Institute: Assessment of Impact and Implications for Faculty Development. Journal of Engineering Education, 99(2), 121-134. doi:DOI 10.1002/j.2168-9830.2010.tb01049.x

33. Feng, L. M., \& Zhao, S. Y. (2016). The Application of Mobile Internet in Teaching and Learning Development of University Young Teacher. Proceedings 2016 Eighth International Conference on Measuring Technology and Mechatronics Automation Icmtma 2016, 700-703. doi:10.1109/Icmtma.2016.172

34. Ford, M., \& Leinonen, T. (2009). MobilED - Mobile Tools and Services Platform for Formal and Informal
Learning. Mobile Learning: Transforming the Delivery of Education and Training, 195-214.

35. Gasmi, A. (2014). Mobile Assisted Language Learning: Potential and Limitations of Using 'Whatsapp' Messenger to Enhance Students Writing Skills. Inted2014: 8th International Technology, Education and Development Conference, 7243-7243.

36. Hamidi, H., \& Chavoshi, A. (2018). Analysis of the essential factors for the adoption of mobile learning in higher education: A case study of students of the University of Technology. Telematics and Informatics, 35(4), 1053-1070. doi:10.1016/j.tele.2017.09.016

37. Heavin, C., \& Neville, K. (2012). Using Social Media Technology as an Educational Tool. Proceedings of the 6th European Conference on Games Based Learning, 194-201.

38. Hussain, I., Cakir, O., \& Candeger, U. (2018). Social Media as a Learning Technology for University Students. International Journal of Instruction, 11(2), 281-296. doi:10.12973/iji.2018.11219a

39. Isasi, R. M. G., \& Morales, G. D. M. (2018). Use of Mobile Devices as Tools for Learning. Pixel-Bit-Revista De Medios Y Educacion(52), 217-227. doi:10.12795/pixelbit.2018.i52.15

40. Jaafar, N. I., Darmawan, B., \& Ariffin, M. Y. M. (2018) Social Networking Site Adoption in Malaysia and Indonesia. Jurnal Komunikasi-Malaysian Journal of Communication, 34(1), 115-134. doi:10.17576/Jkmjc2018-3401-07

41. Jackson, J. (2017). Using Social Media to Support Clinical Education. Journal of Continuing Education in Nursing, 48(12), 541-542. doi:10.3928/0022012420171115-04

42. Joe, H. K., Hiver, P., \& Al-Hoorie, A. H. (2017). Classroom social climate, self-determined motivation, willingness to communicate, and achievement: A study of structural relationships in instructed second language settings. Learning and Individual Differences, 53, 133144. doi:10.1016/Llindif.2016.11.005

43. Junco, R. (2010). Generational Shockwaves and the Implications for Higher Education. Review of Higher Education, 33(3), 419-421.

44. Junco, R. (2012). Too much face and not enough books: The relationship between multiple indices of Facebook use and academic performance. Computers in Human Behavior, 28(1), 187-198. doi:10.1016/j.chb.2011.08.026

45. Kaplan, A. M., \& Haenlein, M. (2010). Users of the world, unite! The challenges and opportunities of Social Media. Business Horizons, 53(1), 59-68. doi:10.1016/j.bushor.2009.09.003

46. Kaur, A., \& Bhullar, M. S. (2013). A New Method of Learning: M-Learning (Mobile Learning). World Congress on Engineering and Computer Science, Wcecs 2013, Vol I, I, 187-+

47. Kerawalla, L., Minocha, S., Kirkup, G., \& Conole, G. (2009). An empirically grounded framework to guide blogging in higher education. Journal of Computer Assisted Learning, 25(1), 31-42. doi:10.1111/j.13652729.2008.00286.x

48. Khadimally, S. (2017). Advancing Higher Education with Mobile Learning Technologies: Cases, Trends, and Inquiry-Based Methods. International Journal of Information and Communication Technology Education, 13(3), 100-102. 
49. Kubey, R. W., Lavin, M. J., \& Barrows, J. R. (2001). Internet use and collegiate academic performance decrements: Early findings. Journal of Communication, 51(2), 366-382. doi:DOI 10.1093/joc/51.2.366

50. Manca, S., \& Ranieri, M. (2016). "Yes for sharing, no for teaching!": Social Media in academic practices. Internet and Higher Education, 29, 63-74. doi:10.1016/j.iheduc.2015.12.004

51. Mikum, S., Suksakulchai, S., Chaisanit, S., \& Murphy, E. (2018). Students' participation in peer-to-peer communication supported by social media. Education and Information Technologies, 23(2), 659-679. doi:10.1007/s10639-017-9628-8

52. Minocha, S., Schroeder, A., \& Schneider, C. (2011). Role of the educator in social software initiatives in further and higher education: A conceptualisation and research agenda. British Journal of Educational Technology, 42(6), 889-903. doi:10.1111/j.14678535.2010.01131.x

53. Mulqueeny, K., Mingle, L. A., Kostyuk, V., Baker, R. S., \& Ocumpaugh, J. (2015). Improving Engagement in an E-Learning Environment. Artificial Intelligence in Education, Aied 2015, 9112, 730-733. doi:10.1007/9783-319-19773-9_103

54. Phielix, C., Prins, F. J., \& Kirschner, P. A. (2010). Awareness of group performance in a CSCLenvironment: Effects of peer feedback and reflection. Computers in Human Behavior, 26(2), 151-161. doi:10.1016/j.chb.2009.10.011

55. Rahman, M. S., Daud, N. M., \& Hassan, H. (2017). Generation " $\mathrm{X}$ " and " $\mathrm{Y}$ " knowledge sharing behaviour The influence of motivation and intention on nonacademic staff of higher learning institutions. Journal of Applied Research in Higher Education, 9(2), 325-342. doi:10.1108/Jarhe-05-2016-0039

56. Rambe, P. (2015). Towards a mobile flipped classroom: Using mobile instant messaging to enhance distributed learning of academically challenged students. 1st International Conference on Higher Education Advances (Head'15), 431-440. doi:10.4995/HEAd15.2015.427

57. Redecker, C., \& Punie, Y. (2010). Learning 2.0 Promoting Innovation in Formal Education and Training in Europe. Sustaining Tel: From Innovation to Learning and Practice, 6383, 308-323.

58. Saeed, N., Yang, Y., \& Sinnappan, S. (2009). Emerging Web Technologies in Higher Education: A Case of Incorporating Blogs, Podcasts and Social Bookmarks in a Web Programming Course based on Students' Learning Styles and Technology Preferences. Educational Technology \& Society, 12(4), 98-109.

59. Schroeder, A., Minocha, S., \& Schneider, C. (2010). The strengths, weaknesses, opportunities and threats of using social software in higher and further education teaching and learning. Journal of Computer Assisted Learning, 26(3), 159-174. doi:10.1111/j.1365-2729.2010.00347.x

60. Tairab, A., Huang, R. H., Taha, M., \& Perris, K. (2017). Mobile Learning in Higher Education in Sudan. 25th International Conference on Computers in Education (Icce 2017), 1033-1035.

61. Tang, S., \& Patrick, M. E. (2018). Technology and interactive social media use among 8th and 10th graders in the US and associations with homework and school grades. Computers in Human Behavior, 86, 34-44. doi:10.1016/j.chb.2018.04.025

62. Tess, P. A. (2013). The role of social media in higher education classes (real and virtual) - A literature review. Computers in Human Behavior, 29(5), A60-A68. doi:10.1016/j.chb.2012.12.032

63. Ting, T. T., Ng, K. S., Ooi, K. H., \& Yap, C. Y. (2018). Current Impact of Social Media on Higher Education Institution Student's Academic Performance in Malaysia.
Advanced Science Letters, 24(4), 2247-2251. doi:10.1166/asl.2018.10927

64. Traxler, J. M. (2013). MOBILE LEARNING ACROSS DEVELOPING AND DEVELOPED WORLDS Tackling Distance, Digital Divides, Disadvantage, Disenfranchisement. Handbook of Mobile Learning, 129141.

65. Traxler, J. M. (2017). Learning with Mobiles in Developing Countries: Technology, Language, and Literacy. International Journal of Mobile and Blended Learning, 9(2), 1-15. doi:10.4018/Ijmbl.2017040101

66. Tsai, P. S., Tsai, C. C., \& Hwang, G. J. (2012). Developing a survey for assessing preferences in constructivist context-aware ubiquitous learning environments. Journal of Computer Assisted Learning, 28(3), 250-264. doi:10.1111/j.1365-2729.2011.00436.x

67. Wankel, C. (2011). New Directions in Teaching Technologies: Introduction to Educating Educators with Social Media. Educating Educators with Social Media, 1, 3-11. doi:10.1108/S2044-9968(2011)0000001003

68. Waycott, J., Sheard, J., Thompson, C., \& Clerehan, R. (2013). Making students' work visible on the social web: A blessing or a curse? Computers \& Education, 68, 8695. doi:10.1016/j.compedu.2013.04.026

69. Werner, V., Lehl, M., \& Walton, J. (2017). Pop Lyrics and Mobile Language Learning: Prospects and Challenges. International Journal of Mobile and Blended Learning, 9(4), 33-48. doi:10.4018/Ijmbl.2017100103

70. White, S., Bloomfield, D., \& Le Cornu, R. (2010). Professional experience in new times: issues and responses to a changing education landscape. AsiaPacific Journal of Teacher Education, 38(3), 181-193. doi:Pii 925233989

71. 10.1080/1359866x.2010.493297

72. Wickramanayake, L., \& Jika, S. M. (2018). Social media use by undergraduate students of education in Nigeria: a survey. Electronic Library, 36(1), 21-37. doi:10.1108/El01-2017-0023

73. Woodill, G. (2015). Using Mobile Devices to Leverage Social Media for Learning. Mastering Mobile Learning. Tips and Techniques for Success, 237-241.

74. Zgoda, K., \& Shane, K. (2018). Digital Literacy in Social Work Education A Case Study Incorporating Technology and Social Media Within the Social Work Curriculum. Journal of Nonprofit Education and Leadership, 8(1), 32-40. doi:10.18666/Jnel-2018-V8-I1-8350

75. Zhang, Z. L., Chong, E. K. P., Pezeshki, A., Moran, W., \& Howard, S. D. (2012). Rate of Learning in Hierarchical Social Networks. 2012 50th Annual Allerton Conference on Communication, Control, and Computing (Allerton), 2010-2017.

76. Zhou, Y. B. (2014). Impact of Mobile Learning on Distance Education. Proceedings of the 2nd International Conference on Teaching and Computational Science, 165-168.

77. Zyoud, S. H., Sweileh, W. M., Awang, R., \& Al-Jabi, S W. (2018). Global trends in research related to social media in psychology: mapping and bibliometric analysis. International Journal of Mental Health Systems, 12. doi:ARTN 410.1186/s13033-018-0182-6 


\section{AUTHORS PROFILE}

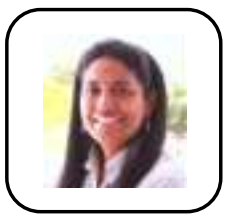

Dr.Kalaimagal Ramakrishnan is currently working at University of Nottingham Malaysia, as an Asst.Professor. With 1 year working experience in the industry and more than 18 years experience in teaching in many International Universities. She teaches Computing modules. Her research interest includes Management Information System, Knowledge Management, Big Data and Education discipline area. In year 2013, she obtained her Doctorate Degree in Computer Science, majoring in Knowledge Management System from University of Malaya, Malaysia. She obtained her first degree from Perth, Australia. In year 2015, she completed the Postgraduate Certificate in Higher Education (PGCHE), UK. She secured a number of Project Grants and publications in Journals and Proceedings.

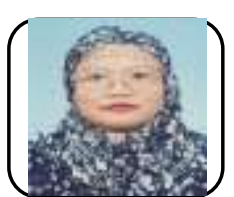

Dr.Norizan binti Mohd Yasin is currently working at University of Malaya, as a Senior Lecturer. With 7 years working experience in the industry and more than 26 years experience in teaching in Universities. She teaches Computing modules. She obtained her first degree and Masters from University of Miami, USA. She obtained her $\mathrm{PhD}$ from University of Manchester, UK. She was the Head of Department of Information System department at the University of Malaya from year 2009 until 2011. Her research interest includes Information, Computer and Communication Technology (ICT), Information Systems (knowledge management, knowledge sharing, knowledge base), Ict Policies (ICT policies, ICT governance, ICT security, ICT audit), Digital Signal Processing (Wireless Technology Application System), Management Information System (Distributed Data Processing), Management Information System (System design), E-Government (Electronic Government), E-Commerce (ECommerce), Enterprise Resource Planning (ERP) systems, Decision Support System (Data Mining), Decision Support System (Knowledge Management), Management Information System and Customer Relationship Management (CRM). She secured a number of $\mathrm{PhD}$ students, Project Grants and publications in Journals and Proceedings.

K R Selvaraj is currently working at University

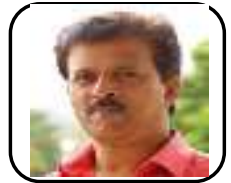
of Nottingham Malaysia, as an Asst.Professor. With 4 years working experience in the industry and more than 15 years experience in teaching in many International Universities. He teaches Computing modules. He obtained his first degree and Masters from a well known University in India. In year 2010, he completed the Postgraduate Certificate in Higher Education (PGCHE), UK. He secured a number of Project Grants and publications in Journals and Proceedings. His research interests fall under the general theme of Intelligent Decision Support mainly focusing on E-Learning. Within this E-Learning context, he is interested in creating a framework for automatically adaptable educational hypermedia systems for non-technical teachers to use in their higher-learning educational environments.

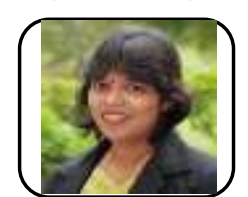

Jeyarani Periasamy is currently working at INTI International University, Nilai, Malaysia. She is working as a lecturer. She has more than 20 years teaching experience at a few Universities in Malaysia She teaches Computing modules and Intelligent Course Management System (ICMS). She obtained her first degree, Bachelor of Information Technology from Otago Polytechnic, New Zealand. She obtained her Masters from Malaysia. She secured a number of publications in Journals and Proceedings. Her research interests fall under Multi-Agent, E-Learning and she is also very active in Teaching and Learning. She has experience teaching Diploma and Degree students. She is active in collaborating with researchers from other universities. 